\title{
tRNA elbow modifications affect the tRNA pseudouridine synthase TruB and the methyltransferase TrmA
}

\author{
SARAH KAI-LEIGH SCHULTZ and UTE KOTHE \\ Alberta RNA Research and Training Institute, Department of Chemistry and Biochemistry, University of Lethbridge, Lethbridge, AB, \\ Canada T1K 3M4
}

\begin{abstract}
tRNAs constitute the most highly modified class of RNA. Every tRNA contains a unique set of modifications, and $\Psi 55$, $m^{5} U 54$, and $m^{7} G 46$ are frequently found within the elbow of the tRNA structure. Despite the abundance of tRNA modifications, we are only beginning to understand the orchestration of modification enzymes during tRNA maturation. Here, we investigated whether pre-existing modifications impact the binding affinity or catalysis by tRNA elbow modification enzymes. Specifically, we focused on the Escherichia coli enzymes TruB, TrmA, and TrmB which generate $\Psi 55, m^{5} U 54$, and $m^{7} G 46$, respectively. tRNAs containing a single modification were prepared, and the binding and activity preferences of purified E. coli TrmA, TruB, and TrmB were examined in vitro. TruB preferentially binds and modifies unmodified tRNA. TrmA prefers to modify unmodified tRNA, but binds most tightly to tRNA that already contains $\Psi 55$. In contrast, binding and modification by TrmB is insensitive to the tRNA modification status. Our results suggest that TrmA and TruB are likely to act on mostly unmodified tRNA precursors during the early stages of tRNA maturation whereas TrmB presumably acts on later tRNA intermediates that are already partially modified. In conclusion, we uncover the mechanistic basis for the preferred modification order in the $E$. coli tRNA elbow region.
\end{abstract}

Keywords: tRNA; RNA modification; pseudouridine; methylation; modification order

\section{INTRODUCTION}

Transfer RNA (tRNA) is the most highly and most diversely modified class of RNA, containing over 100 chemically distinct modifications and a median of twelve modifications per individual tRNA (Boccaletto et al. 2018). In some organisms, more than $1 \%$ of the genome encodes tRNA modification enzymes, highlighting the energetic cost all cells invest in tRNA modification (El Yacoubi et al. 2012) whereas in many organisms including humans the full set of tRNA modification enzymes is not even known yet (de Crecy-Lagard et al. 2019). The model organism Escherichia coli contains over 25 different modifications, with each tRNA containing between three and 13 modifications (Boccaletto et al. 2018).

Two clusters of tRNA modifications are evident in the tRNA tertiary structure. The first cluster of tRNA modifications is found within the tRNA anticodon loop. In general, these modifications are bulky, complex, and each modification is only found within a few isoacceptor tRNAs per organism. Several tRNA anticodon modifications have been shown to play important roles during translation (Ranjan and Rodnina 2016). The second cluster of tRNA modifica-

Corresponding author: ute.kothe@uleth.ca

Article is online at http://www.rnajournal.org/cgi/doi/10.1261/rna. 075473.120. tions is found within the tRNA elbow, a region formed by long-range base-pairing interactions between the $D$ and Tloops.

In contrast to anticodon loop modifications, tRNA elbow modifications are less diverse. For example, 5-methyluridine $\left(\mathrm{m}^{5} \mathrm{U}\right) 54$ (also known as ribothymidine 54 ) and pseudouridine ( $\Psi) 55$ are found within every tRNA in E. coli, where they are introduced by $\operatorname{Trm} A$ and TruB, respectively (Fig. 1A,B). Additionally, $\mathrm{m}^{5} \mathrm{U} 54$ and $\Psi 55$ modifications are found widely within elongator tRNAs throughout all domains of life, including in humans, where these modifications are introduced by the TrmA and TruB homologs TRMT2A and PUS4 in the cytoplasm. Another abundant tRNA elbow modification is 7-methylguanosine $\left(\mathrm{m}^{7} \mathrm{G}\right) 46$ (Fig. 1A,B), which is introduced by TrmB in E. coli and is frequently found within tRNAs containing short variable loops (Purta et al. 2005). TrmB is also widely conserved, with METTL1 as its human homolog. Within bacteria, 4-thiouridine $\left(s^{4} U\right) 8$ is a common modification and is catalyzed by Thil, which requires sulfur transfer by IscS (Fig. 1A,B;

(c) 2020 Schultz and Kothe This article is distributed exclusively by the RNA Society for the first 12 months after the full-issue publication date (see http://rnajournal.cshlp.org/site/misc/terms.xhtml). After 12 months, it is available under a Creative Commons License (Attribution-NonCommercial 4.0 International), as described at http:// creativecommons.org/licenses/by-nc/4.0/. 
A

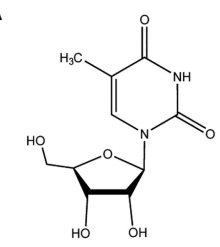

5-methyluridine $\left(\mathrm{m}^{5} \mathrm{U}\right)$

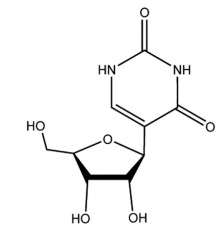

pseudouridine $(\Psi)$ 7-methylguanosine $\left(m^{7} G\right)$
B

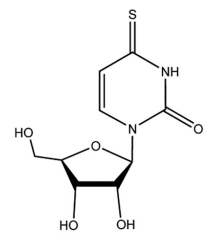

4-thiouridine $\left(\mathrm{s}^{4} \mathrm{U}\right)$

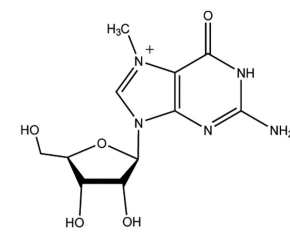

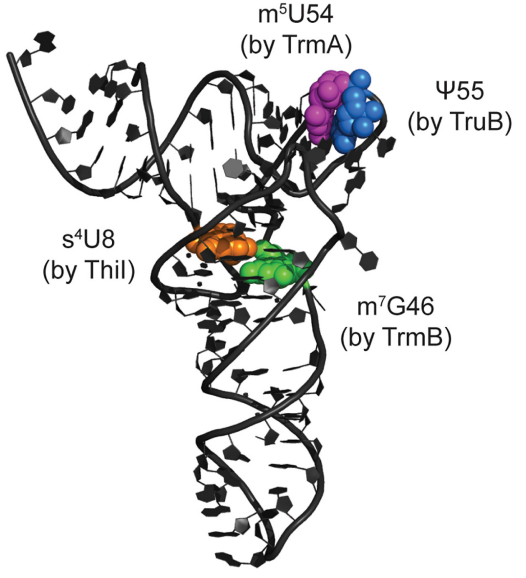

FIGURE 1. Structures of selected tRNA elbow modifications and their locations within $E$. coli tRNA ${ }^{\text {Phe }}$. (A) Structures of the 4-thiouridine, 7-methylguanosine, 5-methyluridine, and pseudouridine modifications. $(B)$ The locations of these modifications within the tRNA elbow are highlighted as spheres within the crystal structure of unmodified tRNA ${ }^{\text {Phe }}$ (PDB 3LOU; Byrne et al. 2010). The enzyme responsible for each modification is indicated next to the respective modification site.

Kambampati and Lauhon 2000). tRNA elbow modifications are generally considered to be important for promoting tRNA structure and cellular stability (Alexandrov et al. 2006; Kimura and Waldor 2019); however, modifications within the tRNA elbow also have roles during translation. Specifically, E. coli TruB has been found to be important for the translation of consecutive arginine CGA codons (Urbonavicius et al. 2002), and Pseudomonas aeruginosa TrmB is important for the expression of genes enriched in phenylalanine and aspartate codons (Thongdee et al. 2019). In addition to the direct stabilizing effects of tRNA modifications on tRNA structure, two tRNA elbow modification enzymes, namely TruB and TrmA, have been described as tRNA chaperones that help tRNA to adopt its overall L-shaped fold independent of their modification activity (Keffer-Wilkes et al. 2016; LC Keffer-Wilkes, EF Soon, and U Kothe, in prep.).

Here, we are specifically focusing on the pseudouridine synthase TruB, and the two methyltransferases TrmA and TrmB. TruB utilizes a catalytic aspartate residue in conjunction with a conserved arginine and a second-shell aspartate residue to catalyze the isomerization of uridine to pseudouridine (Friedt et al. 2014). Specifically, the catalytic aspartate attacks the $2^{\prime}$ oxygen of the ribose to form a glycal intermediate and to break the $\mathrm{N}-\mathrm{C}$ glycosidic bond. Upon rotation of the uracil base, a new C-C glycosidic bond is formed and the covalent bond to the catalytic aspartate is broken (Veerareddygari et al. 2016). TrmA and TrmB both use S-adenosylmethionine (SAM) as the methyldonor. During tRNA methylation by TrmA, a catalytic cysteine residue forms a covalent bond with $\mathrm{C} 6$ in the uracil ring enabling methyltransfer from SAM to the base. Subsequently, a catalytic glutamate residue acts a general base abstracting a proton from the uracil ring, allowing the covalent bond to the catalytic cysteine to be broken (Alian et al. 2008). The catalytic mechanism of $\mathrm{TrmB}$ methylating G46 is not known yet, but a conserved aspartate residue (D144 in E. coli) is essential for catalysis (Purta et al. 2005). It has been suggested that the catalytic aspartate acts as a general base deprotonating G46 such that the base can attack the SAM cofactor for methyltransfer (Tomikawa 2018).

Despite the abundance and importance of tRNA modifications, we are still in the early stages of understanding the multistep process through which tRNA is modified. From previous mechanistic studies, it is known that the majority of tRNA modification enzymes, including TrmA, TruB, TrmB, and Thil, are active on in vitro transcribed, unmodified tRNA (Kambampati and Lauhon 2000; Wright et al. 2011; Thongdee et al. 2019; LC Keffer-Wilkes, EF Soon, and U Kothe, in prep.); however, completely unmodified tRNA may not be the preferred substrate of these enzymes in vivo. Recent reviews have emphasized that the order of tRNA modification is likely not random (Han and Phizicky 2018; Sokolowski et al. 2018; Barraud and Tisne 2019). In particular, five so-called "tRNA modification circuits" within the tRNA anticodon loop have been well-described where introduction of a certain modification strictly depends on the prior presence of another modification (Han and Phizicky 2018). Within the tRNA elbow, temperature-specific networks of tRNA modifications have been reported in Thermus thermophilus (Hori 2019). Additionally, a sequential formation of tRNA elbow modifications has been described recently for Saccharomyces cerevisiae system, wherein the modification of in vitro transcribed yeast tRNA ${ }^{\text {Phe }}$ by yeast cell extract was monitored over time. $\Psi 55$ was found to be fully introduced within the tRNA population prior to the appearance of any other modification, followed by $\mathrm{m}^{5} \mathrm{U} 54$ and $m^{7} \mathrm{G} 46$, then $\mathrm{m}^{2} \mathrm{G} 10, \mathrm{D} 16$, and $\mathrm{m}^{5} \mathrm{C} 49$, and finally $\mathrm{m}^{1} \mathrm{~A} 58$ (Barraud et al. 2019). This study provides strong evidence that modifications in the tRNA elbow region are not introduced randomly, but the molecular determinants of the sequential modification order remain unclear.

Therefore, the goal of this study was to examine the impact of tRNA modification status on the in vitro binding and catalytic activity of $E$. coli tRNA elbow modification enzymes TruB, TrmA, and TrmB. Specifically, by conducting quantitative biochemical experiments, we aimed to not only identify the preferred tRNA substrate for these enzymes, but to also characterize the molecular basis for 
the ordered modification of tRNA in the elbow region. To accomplish this, we prepared in vitro transcribed tRNA that contained a single modification for use in enzyme binding and activity assays. Here, we report that TruB prefers to bind and modify tRNA that does not yet contain any modifications, whereas TrmA prefers to modify unmodified tRNA, but has a binding preference for tRNA already containing the $\Psi 55$ modification. This proof-of-principle study suggests tRNA elbow modification enzymes are sensitive to the modification status of their substrate tRNAs, explaining why the order of tRNA elbow modification is not completely random.

\section{RESULTS}

In order to determine the effect of a pre-existing tRNA modification on the affinity and activity of another tRNA modification enzyme, we used in vitro transcribed E. coli tRNA $^{\text {Phe }}$ as a model substrate. Single-modified tRNA ${ }^{\text {Phe }}$ was prepared by incubation with purified E. coli TrmA, TruB, TrmB, or Thil and IscS. Each single-modified tRNA contained one modification at a level of at least $78 \%$ (see Materials and Methods). Unmodified tRNA as well as single-modified tRNAs were subsequently used in binding and activity assays in order to compare whether TrmA, TruB, or TrmB prefer binding and/or modifying tRNA with a certain modification status.

\section{Binding and activity preferences of TruB}

To assess whether TruB prefers to bind and modify unmodified tRNA or tRNA already containing a single modification, we prepared tritium-labeled tRNA ${ }^{\text {Phe }}$ containing $s^{4} \cup 8, m^{7} G 46$, or $m^{5} \cup 54$. First, we compared the activity of TruB under multiple-turnover conditions with unmodified tRNA and tRNA containing $\mathrm{m}^{7} \mathrm{G} 46$ or $\mathrm{m}^{5} \mathrm{U} 54$ using tritium release assays. At a tRNA concentration of $600 \mathrm{nM}$ (near its Michaelis constant, $K_{\mathrm{M}}, 550 \mathrm{nM}$ ), $10 \mathrm{nM}$ TruB has an initial velocity of approximately $4.7 \mathrm{nM} \mathrm{s}^{-1}$ for pseudouridylating unmodified tRNA (Table 1; Fig. 2A), as previously

TABLE 1. Average multiple-turnover initial velocities $\left(v_{0}, n M\right.$ $\mathrm{s}^{-1}$ ) for TruB and TrmA modifying different single-modified tRNAs

\begin{tabular}{lcc}
\hline tRNA $^{\text {Phe }}$ modification & TruB & TrmA \\
\hline Unmodified & $4.7 \pm 0.6$ & $4.5 \pm 0.9$ \\
$\mathrm{~m}^{7}$ G46 & $1.6 \pm 0.5$ & $2.4 \pm 0.6$ \\
$\mathrm{~m}^{5} \mathrm{U} 54$ & $3.8 \pm 0.6$ & $\mathrm{NA}$ \\
$\Psi 55$ & $\mathrm{NA}$ & $2.7 \pm 0.7$ \\
\hline
\end{tabular}

Initial velocities are provided with standard deviation as determined in at least three independent experiments. Initial velocities cannot be determined for a tRNA that contains already the respective modification made by TruB or TrmA as indicated by NA (not applicable). reported (Wright et al. 2011). Introduction of the adjacent $\mathrm{m}^{5} \mathrm{U} 54$ modification did not significantly affect the initial rate of TruB for tRNA ${ }^{\text {Phe; }}$; however, incorporation of $\mathrm{m}^{7} \mathrm{G} 46$ into the tRNA lowered the initial velocity of pseudouridylation by TruB almost threefold to $1.6 \mathrm{nM} \mathrm{s}^{-1}$ (Table 1; Fig. 2A). The presence of $\mathrm{s}^{4} \mathrm{U} 8$ did not significantly affect single-turnover TruB rate (Table 2; Fig. 2B).

In order to reveal whether the decreased speed of TruB modification for tRNA containing $\mathrm{m}^{7} \mathrm{G} 46$ was caused by a decrease in the binding affinity of TruB for this tRNA, dissociation constants $\left(K_{\mathrm{D}}\right)$ were determined using nitrocellulose filtration assays. The catalytically inactive TruB D48N variant was used in order to measure the affinity of TruB for its substrate tRNA, rather than for its product, tRNA $^{\text {Phe }} \Psi 55$. As reported previously, the dissociation constant of TruB D48N for unmodified tRNA is $1.4 \mu \mathrm{M}$ (Table 3; Fig. 2C; Wright et al. 2011) and thus slightly lower than the dissociation constant of TruB wild-type for pseudouridylated tRNA (2.4 $\mu \mathrm{M})$ (Keffer-Wilkes et al. 2016). When $m^{7} \mathrm{G} 46$ is present within the tRNA, the affinity of TruB D48N is reduced approximately twofold with a dissociation constant of about $3.1 \mu \mathrm{M}$ (Table 3 ; Fig. 2C), in accordance with the decrease in TruB initial velocity for tRNA $\mathrm{m}^{7} \mathrm{G} 46$ (Table 1; Fig. 2A). Interestingly, the presence of either $s^{4} \cup 8$ or $m^{5} \cup 54$ also lowered the affinity of TruB D48N for tRNA ${ }^{\text {Phe }}$ approximately twofold (Table 3; Fig. 2C), despite the fact these modifications did not significantly lower the initial velocity of TruB modification (Table 1; Fig. 2A,B). TruB D48N binding to tRNA ${ }^{\text {Phe }} \Psi 55$, the product of TruB, was found to be similar to TruB D48N binding to its unmodified substrate tRNA ${ }^{\text {Phe }}$. In summary, the presence of $s^{4} \cup 8, m^{7} G 46$, or $m^{5} \cup 54$ (but not 455) lowered the affinity of TruB D48N, highlighting that $s^{4} \cup 8, m^{7} G 46$, and $m^{5} \cup 54$ significantly and negatively affect TruB binding to tRNA (Table 3; Fig. 2D).

Next, we wanted to examine whether the presence of multiple modifications further decreased the affinity of TruB for tRNA. Therefore, $\left[{ }^{3} \mathrm{H}\right] \mathrm{tRNA} \mathrm{A}^{\text {Phe }}$ containing five modifications, namely two pseudouridines in the anticodon loop ( $\Psi 32$ and $\Psi 38$ introduced by RluA and TruA), as well as $m^{7} G 46, m^{5} U 54$, and $\Psi 55$ was prepared. The affinity of TruB for this tRNA was found to be further decreased compared to the single-modified tRNA variants with a $K_{\mathrm{D}}$ of about $6.4 \mu \mathrm{M}$ (Table 3; Fig. 2D), further suggesting TruB prefers to bind to tRNA prior to modification by other enzymes. Taken together, these results indicate that the binding of TruB to tRNA is sensitive to the presence of single $s^{4} \cup 8, m^{7} G 46$, and $m^{5} \cup 54$ modifications, with $\mathrm{m}^{7} \mathrm{G} 46$ additionally lowering the reaction velocity of pseudouridylation by TruB.

\section{Binding and activity presence of TrmA}

Similarly, we tested the impact of prior modifications on the TrmA enzyme using single-modified, tritium-labeled 

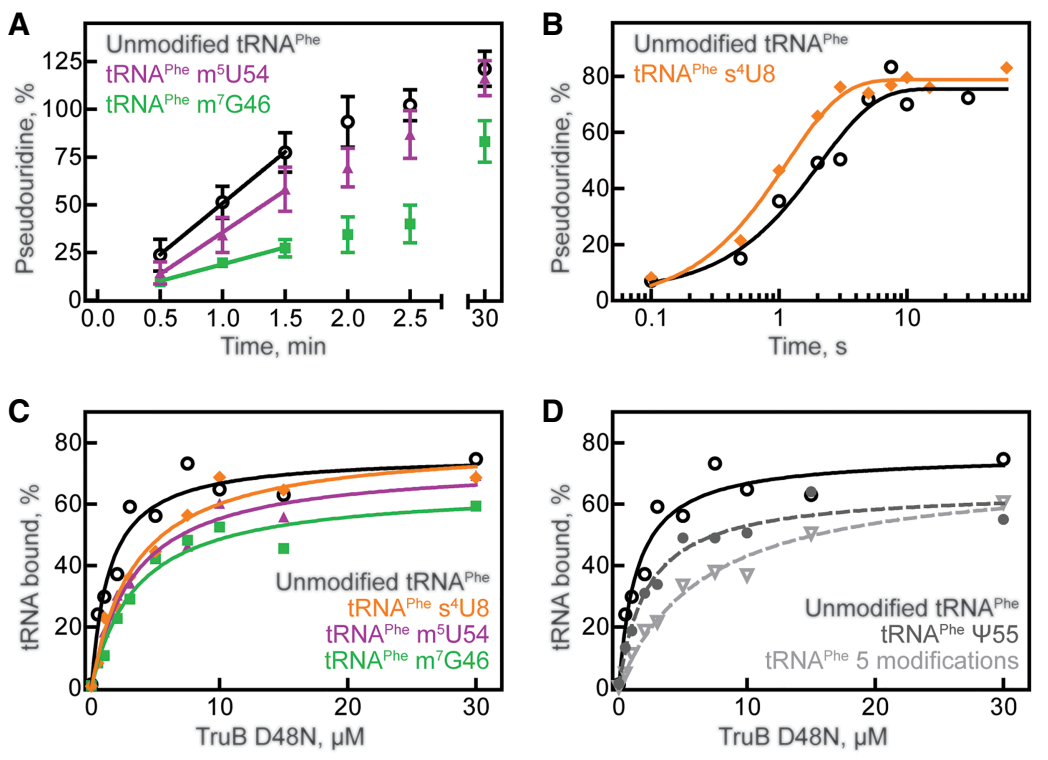

FIGURE 2. tRNA modification and binding preferences of TruB. (A) Multiple-turnover modification by $10 \mathrm{nM}$ TruB incubated with $600 \mathrm{nM}$ unmodified tRNA ${ }^{\text {Phe }}$ (open circles), tRNA ${ }^{\text {Phe }}$ $\mathrm{m}^{5} \mathrm{U} 54$ (purple triangles), or tRNA ${ }^{\text {Phe }} \mathrm{m}^{7} \mathrm{G} 46$ (green squares). Time courses were performed at least in triplicate, and initial velocities were determined by linear regression (see Table 1). (B) Single-turnover modification by $5 \mu \mathrm{M}$ TruB incubated with $1 \mu \mathrm{M}$ unmodified tRNA ${ }^{\text {Phe }}$ (open circles) or tRNA ${ }^{\text {Phe }} s^{4} \cup 8$ (orange diamonds). Here, we show one representative time course, but each time course was performed in triplicate and the apparent rate of each reaction was determined by fitting with a one-exponential equation, summarized in Table 2. Binding of catalytically inactive TruB D48N to $20 \mathrm{nM}(C)$ unmodified tRNA ${ }^{\text {Phe }}$ (open circles), tRNA ${ }^{\text {Phe }}$ $\mathrm{m}^{5} \mathrm{U} 54$ (purple triangles), tRNA ${ }^{\text {Phe }} \mathrm{m}^{7} \mathrm{G} 46$ (green squares), tRNA ${ }^{\text {Phe }} \mathrm{s}^{4} \cup 8$ (orange diamonds), or to (D) tRNA ${ }^{\text {Phe }} \Psi 55$ (gray circles, dashed line), or tRNA ${ }^{\text {Phe }}$ containing $s^{4} \cup 8, \Psi 32, \Psi 38$, $m^{7} \mathrm{G} 46, \mathrm{~m}^{5} \mathrm{U} 54$, and $\Psi 55$ (light gray inverted triangles, dashed line), unmodified tRNA ${ }^{\text {Phe }}$ (same as shown in C) determined by nitrocellulose filtration. One representative curve each of at least three replicates is shown. The data were fit with a hyperbolic equation to determine the dissociation constant, $K_{\mathrm{D}}$ (see Table 3).

tRNA $^{\text {Phe }}$ in multiple-turnover tritium release assays. When acting on unmodified tRNA ${ }^{\text {Phe }}$, the initial velocity of TrmAcatalyzed methylation is about $4.5 \mathrm{nM} \mathrm{s}^{-1}$ (Table 1; Fig. 3A). The initial velocity of TrmA modification is reduced about twofold when either $\mathrm{m}^{7} \mathrm{G} 46$ or $\Psi 55$ are present, to $2.4 \mathrm{nM} \mathrm{s}^{-1}$ and $2.7 \mathrm{nM} \mathrm{s}^{-1}$, respectively (Table 1; Fig. $3 A)$. It is interesting that the initial velocity of TrmA is slower when $\Psi 55$, the modification introduced by TruB, is present, because the affinity of TruB was reduced when the modification introduced by $\operatorname{TrmA}, \mathrm{m}^{5} \mathrm{U} 54$, was present within tRNA ${ }^{\text {Phe }}$ (Table 3; Fig. 2C), suggesting previous TruB modification negatively affects modification by TrmA and vice versa.

To further examine the impact of the adjacent $\Psi 55$ modification on catalysis by $\operatorname{TrmA}$, the apparent rate of tRNA methylation by TrmA was compared for unmodified tRNA ${ }^{\text {Phe }}$ and tRNA ${ }^{\text {Phe }} \Psi 55$ using tritium release assays under single-turnover conditions in a quench-flow apparatus. In the absence and presence of the $\Psi 55$ modification, the apparent rate was found to be about 0.08 and $0.06 \mathrm{~s}^{-1}$, respectively, suggesting that $\Psi 55$ modification does not significantly affect catalysis by TrmA (Table 2; Fig. 3B). As observed with TruB, the presence of $s^{4} \cup 8$ also did not affect the apparent rate of TrmA (Table 2; Fig. 3B).

Next, we examined the influence of tRNA modification status on TrmA tRNA binding by nitrocellulose filter binding. Here, the TrmA C324A variant was used because this variant is deficient in catalysis and because it cannot form a covalent bond between enzyme and substrate (Kealey et al. 1994). The affinity of TrmA C324A for unmodified tRNA ${ }^{\text {Phe }}$ was found to be about $0.9 \mu \mathrm{M}$ (Table 3; Fig. 3C). The presence of the $\mathrm{m}^{7} \mathrm{G} 46$ modification lowered the affinity of TrmA C324A for tRNA ${ }^{\text {Phe }}$ twofold to a dissociation constant of $1.9 \mu \mathrm{M}$ (Table 3; Fig. 3C), consistent with the observation that this modification results in a reduction of the initial velocity of TrmA (Table 1; Fig. 3A). Similarly, we assessed the affinity of TrmA C324A for the product tRNA $m^{5} \cup 54$ and determined a reduced affinity compared to unmodified tRNA (Table 3; Fig. 3D). In other words, the affinity of TrmA C324A for tRNA ${ }^{\text {Phe }} m^{7} G 46$ is similar to the affinity of TrmA C324A for tRNA $\mathrm{m}^{5} \mathrm{U} 54$. The presence of $s^{4} \cup 8$ did not affect TrmA C324A binding (Table 3; Fig. 3D), in agreement with the lack of effect of this modification on TrmA activity (Table 2; Fig. 3A).

Interestingly, the presence of the $\Psi 55$ modification strongly improved the affinity of TrmA C324A for tRNA $\Psi 55$ almost fivefold compared to unmodified tRNA ${ }^{\text {Phe }}$ (Table 3; Fig. 3C), contrasting the twofold decrease in TrmA activity for tRNA ${ }^{\text {Phe }} \Psi 55$ (Table 1; Fig. 3A). Given that $\Psi 55$ does not affect the rate constant of catalysis by

TABLE 2. Average single-turnover apparent rates for TruB $\left(k_{\Psi}\right.$, $\left.\mathrm{s}^{-1}\right)$, TrmA $\left(k_{\text {methyl }}, \mathrm{s}^{-1}\right)$, and TrmB $\left(k_{\mathrm{app}}, \mathrm{s}^{-1}\right)$ modifying different single-modified tRNAs

\begin{tabular}{lccc}
\hline tRNA $^{\text {Phe }}$ modification & TruB & TrmA & TrmB \\
\hline Unmodified & $0.5 \pm 0.3$ & $0.08 \pm 0.03$ & $0.2 \pm 0.02$ \\
$\mathrm{~m}^{5} \cup 54$ & $\mathrm{ND}$ & $\mathrm{NA}$ & $0.3 \pm 0.05$ \\
$\Psi 55$ & $\mathrm{NA}$ & $0.06 \pm 0.02$ & $0.2 \pm 0.05$ \\
$\mathrm{~s}^{4} \cup 8$ & $0.7 \pm 0.3$ & $0.09 \pm 0.03$ & $\mathrm{ND}$ \\
\hline
\end{tabular}

Apparent rates are provided with standard deviation as determined in at least three independent experiments. For certain tRNAs, single-turnover apparent rates were not determined (ND), whereas formation of the same modification cannot be determined (not applicable, NA). 

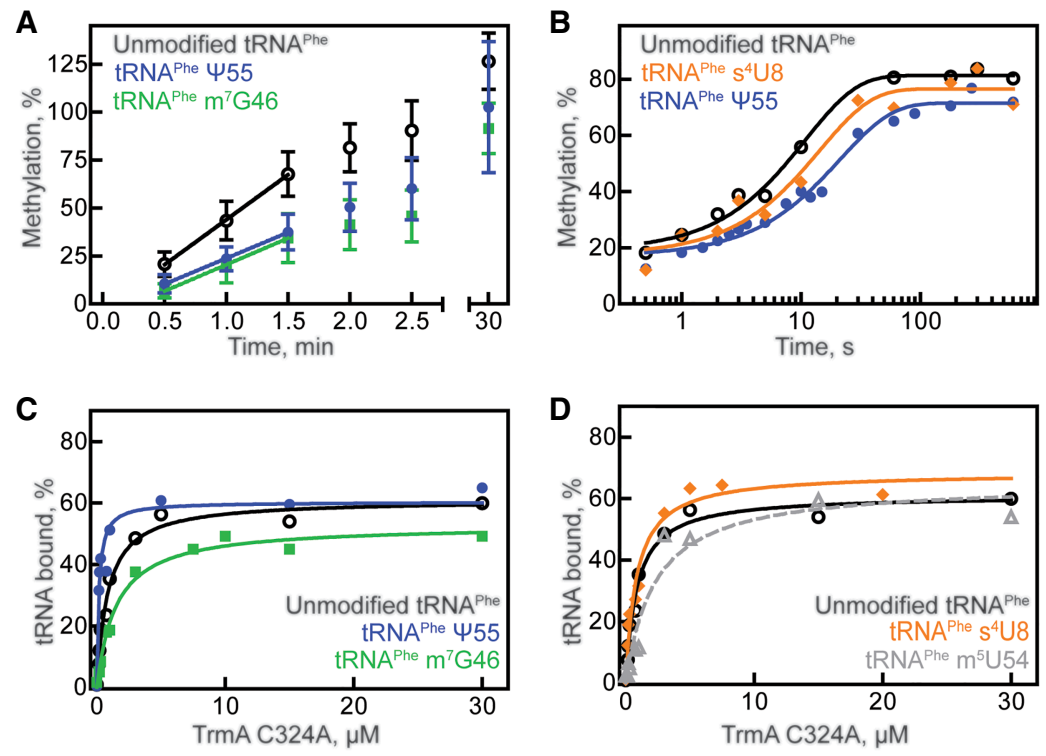

FIGURE 3. tRNA modification and binding preferences for TrmA. (A) Multiple-turnover modification reaction of $10 \mathrm{nM}$ TrmA incubated with $600 \mathrm{nM}$ unmodified tRNA ${ }^{\text {Phe }}$ (open circles), tRNA ${ }^{\text {Phe }} \mathrm{m}^{7} \mathrm{G} 46$ (green squares), or tRNA ${ }^{\text {Phe }} \Psi 55$ (blue circles). Time courses were performed at least in triplicate. Initial velocities are summarized in Table 1. (B) Single-turnover modification by $5 \mu \mathrm{M}$ TrmA and $50 \mu \mathrm{M}$ SAM rapidly mixed with $1 \mu \mathrm{M}$ unmodified tRNA ${ }^{\text {Phe }}$ (open circles), tRNA $^{\text {Phe }} s^{4} \cup 8$ (orange diamonds), or tRNA ${ }^{\text {Phe }} \Psi 55$ (blue circles). Here, individual representative time courses are displayed, and the average apparent rates from three replicates is summarized in Table 2. Catalytically inactive TrmA C324A variant binding to $20 \mathrm{nM}(C)$ unmodified tRNA $^{\text {Phe }}$ (open circles), tRNA ${ }^{\text {Phe }} \mathrm{m}^{7} \mathrm{G} 46$ (green squares), tRNA ${ }^{\text {Phe }} \Psi 55$ (blue circles), or to (D) unmodified tRNA ${ }^{\text {Phe }}$ (black circles, same as shown in C), $t R N A^{\text {Phe }} s^{4} \cup 8$ (orange diamonds), or tRNA ${ }^{\text {Phe }} \mathrm{m}^{5} \mathrm{U} 54$ (gray triangles, dashed line). The average $K_{D}$ from at least three replicates for each experiment is summarized in Table 3.

TrmA (Table 2; Fig. 3B) and $\Psi 55$ increases the affinity of TrmA for tRNA ${ }^{\text {Phe }}$ (Table 3; Fig. 3C), the multiple-turnover activity of TrmA is surprisingly slow on tRNA ${ }^{\text {Phe }} \Psi 55$ compared to unmodified tRNA (Table 1; Fig. 3A). As further discussed below, these findings suggest that $\Psi 55$ must hinder another reaction step such as product release during tRNA modification by TrmA.

\section{Binding and activity preferences of TrmB}

Finally, we examined whether or not the methyltransferase TrmB is sensitive to the modification status of tRNA. In order to examine the single-turnover apparent rate for TrmB modifying tRNAs with different modification statuses, we measured radioactive methyl incorporation from tritium-labeled SAM into nonradioactive tRNA under single-turnover conditions. TrmB was found to modify tRNA ${ }^{\text {Phe }}$ containing no modifications at a rate of about $0.2 \mathrm{sec}^{-1}$, and the rate of modification was similar for tRNA ${ }^{\text {Phe }}$ containing either $\mathrm{m}^{5} \mathrm{U} 54$ or $\Psi 55$ (Table 2; Fig. 4A), suggesting TrmB does not have an activity preference for either unmodified or tRNA that is partially modified in the T loop.

Subsequently, we determined the affinity of TrmB for unmodified tRNA and tRNA containing either $\mathrm{m}^{5} \mathrm{U} 54$ or $\Psi 55$ which may differ even though no changes in the mod- ification rate were observed. Here, wild-type TrmB was used, but the cofactor SAM was omitted from the reaction such that TrmB is not capable of forming product. The affinity of TrmB for tRNA ${ }^{\text {Phe }}$ containing either $\mathrm{m}^{5} \mathrm{U} 54$ or $\Psi 55$ was similar to that of TrmB binding to unmodified tRNA $^{\text {Phe }}$, characterized by a $K_{\mathrm{D}}$ of approximately 3-4 $\mu \mathrm{M}$ (Table 3; Fig. 4B). Similarly, the presence of both $\mathrm{m}^{5} \mathrm{U} 54$ and $\Psi 55$ modifications together did not impact the affinity of TrmB for tRNA $^{\text {Phe }}$ (Table 3; Fig. 4C). Like several other tRNA modification enzymes, TrmB was found to bind its product (tRNA $\mathrm{m}^{7} \mathrm{G} 46$ ) with a similar affinity as its substrate tRNA (Table 3; Fig. 4C). Our results point toward an insensitivity of TrmB binding and activity to the tRNA modification status in the Tloop.

\section{DISCUSSION}

In this study, we examined the effects of single modifications within tRNA ${ }^{\text {Phe }}$ on the activity and affinity of tRNA modification enzymes TruB, TrmA, and TrmB. We report here that the tRNA binding and modification activities of TruB and TrmA are sensitive to the modification status of the substrate tRNA. In contrast, none of the modifications examined here affected either tRNA binding or activity by TrmB. In the following, we will first discuss the molecular basis of how prior tRNA modifications affect (or do not affect) the molecular and kinetic mechanism of TruB, TrmA, and $\operatorname{TrmB}$ (Fig. 5A) before considering the cellular consequences and preferential modification order for tRNA maturation.

\section{Impact of modifications on tRNA binding and catalysis by other modification enzymes}

Of the tested enzymes, TruB is most sensitive to the presence of other modifications in tRNA. We observed that $\mathrm{m}^{7} \mathrm{G} 46$ decreases the initial reaction velocity of pseudouridine formation by TruB and decreases the affinity of TruB for tRNA (Tables 1,3). In addition, the modifications $m^{5} \cup 54$ and $s^{4} \cup 8$ also decrease the affinity of TruB for tRNA although the formation of pseudouridine is not affected (Tables 1-3). Based on the structure of TruB with an unmodified T arm (PDB ID $1 \mathrm{~K} 8 \mathrm{~W}$ ), only $\mathrm{m}^{5} \mathrm{U} 54$ will be in contact with TruB whereas $\mathrm{s}^{4} \mathrm{U} 8$ and $\mathrm{m}^{7} \mathrm{G} 46$ are predicted to be distant from TruB (Hoang and Ferre-D'Amare 
TABLE 3. Average dissociation constants $\left(K_{D}, \mu M\right)$ for TruB TrmA, and TrmB binding to differently modified tRNAs

\begin{tabular}{lccc}
\hline tRNA $^{\text {Phe }}$ modification(s) & TruB & TrmA & TrmB \\
\hline Unmodified & $1.4 \pm 0.3$ & $0.9 \pm 0.2$ & $4.5 \pm 1.9$ \\
$\mathrm{~m}^{7} \mathrm{G} 46$ & $3.1 \pm 0.8$ & $1.9 \pm 0.6$ & $3.1 \pm 1.3$ \\
$\mathrm{~m}^{5} \mathrm{U} 54$ & $3.4 \pm 1.4$ & $2.3 \pm 0.7$ & $3.7 \pm 1.1$ \\
$\Psi 55$ & $2.3 \pm 0.9$ & $0.2 \pm 0.1$ & $3.8 \pm 1.7$ \\
$\mathrm{~s}^{4} \mathrm{U} 8$ & $3.2 \pm 0.9$ & $0.8 \pm 0.2$ & $\mathrm{ND}$ \\
$\mathrm{m}^{5} \mathrm{U} 54, \Psi 55$ & $\mathrm{ND}$ & $\mathrm{ND}$ & $3.7 \pm 0.5$ \\
$\Psi 32, \Psi 38, \mathrm{~m}^{7} \mathrm{G} 46$, & $6.4 \pm 1.4$ & $\mathrm{ND}$ & $\mathrm{ND}$ \\
$\mathrm{m}^{5} \mathrm{U} 54, \Psi 55$ & & & \\
\hline
\end{tabular}

Dissociation constants $\left(K_{\mathrm{D}}\right)$ are provided with standard deviation as determined in at least three independent experiments. Selected dissociation constants were not determined (ND).

2001). Within the unmodified $T$ arm in the TruB structure, U54 forms a base pair with A58 and is contacted by the thumb loop in TruB (residues 120 to 149). Specifically, the side chain of Lysine 130 and the backbone oxygen of Alanine 128 interact with each other and are in very close proximity of C 5 of U54 ( 3.6 and $3.8 \AA$, respectively) leaving no space for an additional methyl group (Fig. 5B). The steric clash between the methyl group of $\mathrm{m}^{5} \mathrm{U} 54$ and Lysine 130 explains the decreased affinity of TruB for tRNA with $\mathrm{m}^{5} \mathrm{U} 54$ compared to unmodified tRNA and suggests that the thumb loop of TruB must undergo a conformational change to accommodate this modification. We speculate that within the kinetic mechanism of TruB, the presence of $m^{5} U 54$ could lead to a faster dissociation of tRNA compared to unmodified tRNA ( $k_{-1}$ and $k_{-2}$, Fig. 5; KefferWilkes et al. 2016). However, since the catalysis of pseudouridylation is the slow and rate-limiting step for TruB (Wright et al. 2011), which is not affected by $m^{5} U 54$ once bound, no change in the reaction velocity is observed.

As s ${ }^{4} \cup 8$ and $m^{7} \mathrm{G} 46$ are not in contact with TruB, their effects on TruB's activity must be indirect and communicated through the tRNA structure. Structural and functional evidence clearly shows that TruB must break interactions between the $T$ and $D$ arm to gain access to the target U55 (Hoang and Ferre-D'Amare 2001; Keffer-Wilkes et al. 2016). Both $s^{4} \cup 8$ and $m^{7} G 46$ stabilize the $D$ arm in mature tRNA as a part of a strong network of tertiary interactions in tRNA in this region (Helm 2006). Notably, the methylation of G46 introduces a positive charge in the variable loop near the negatively charged backbone of the base of the $D$ arm, thereby acting like a staple closely connecting the variable loop and the $D$ arm. Similarly, $s^{4} U 8$ is also interacting with the $D$ arm. By positioning and stabilizing the $D$ arm, $m^{7} G 46$ and $s^{4} \cup 8$ may render it more difficult for TruB to disrupt the tRNA elbow structure, to displace the $D$ arm, and to gain access to U55. Accordingly, we hypothesize that both modifications slow down the conformational change $\left(k_{2}\right)$ thereby decreasing the affinity of
TruB for tRNA (Fig. 5A). In the case of $\mathrm{m}^{7} \mathrm{G} 46$, the initial velocity of pseudouridylation is also affected (Table 1). We can envision that the constrained location of the $D$ arm may affect correct positioning of the T arm within the active site thereby slowing down catalysis.

The negative impact of $s^{4} \cup 8$ and $m^{5} U 54$ on TruB's affinity for tRNA (Table 3 ) is reminiscent of tRNA binding by ArcTGT, for which a negative correlation was observed between $K_{\mathrm{M}}$ and tRNA melting temperature causing ArcTGT modification of unmodified tRNA to be quick in comparison to modification of tRNA containing all modifications except for its product, archaeosine (Nomura et al. 2016). This similarity between ArcTGT and TruB is notable since both enzymes disrupt the tRNA tertiary structure in order

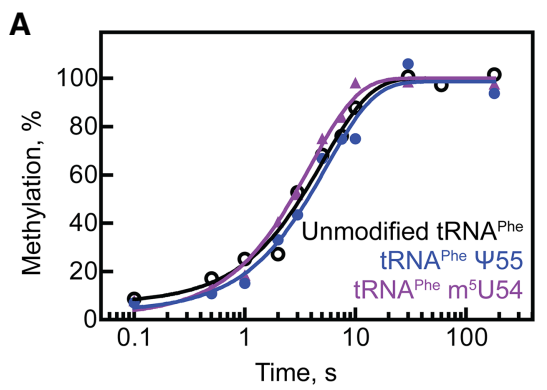

B
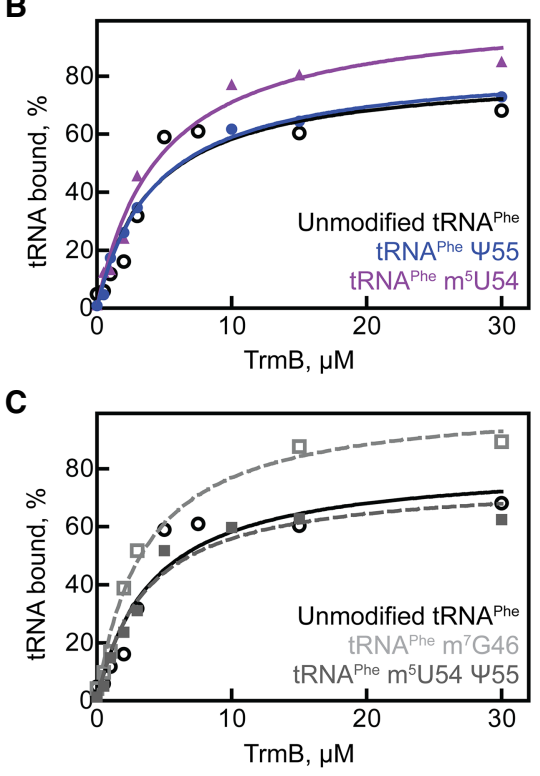

FIGURE 4. tRNA modification and binding preferences for TrmB. (A) Single-turnover modification by $5 \mu \mathrm{M}$ TrmB and $50 \mu \mathrm{M}\left[{ }^{3} \mathrm{H}\right] \mathrm{SAM}$ mixed with $1 \mu \mathrm{M}$ unmodified tRNA $^{\text {Phe }}$ (open circles), tRNA ${ }^{\text {Phe }}$ $\mathrm{m}^{5} \mathrm{U} 54$ (purple triangles), or tRNA ${ }^{\text {Phe }} \Psi 55$ (blue circles). The average apparent rate of modification from three time courses (one representative each shown here) is reported in Table 2. TrmB binding to $20 \mathrm{nM}$ $(B)$ unmodified tRNA ${ }^{\text {Phe }}$ (open circles), tRNA ${ }^{\text {Phe }} \mathrm{m}^{5} \mathrm{U} 54$ (purple triangles), tRNA ${ }^{\text {Phe }} \Psi 55$ (blue circles), or to $(C)$ unmodified tRNA ${ }^{\text {Phe }}$ (black circles, same as shown in B), tRNA ${ }^{\text {Phe }} \mathrm{m}^{5} \mathrm{U} 54 \Psi 55$ (gray squares, dashed line), or tRNA ${ }^{\text {Phe }} \mathrm{m}^{7} \mathrm{G} 46$ (open squares, dashed line). The experiments were repeated at least three times, and the average $K_{D}$ for each tRNA is summarized in Table 3. 
A Initial Docking

Conformational change in tRNA Enzyme
+ tRNA $k_{2}$

B

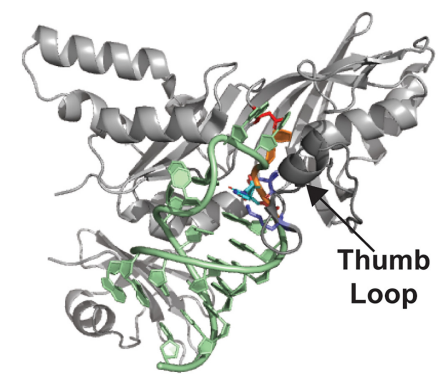

C

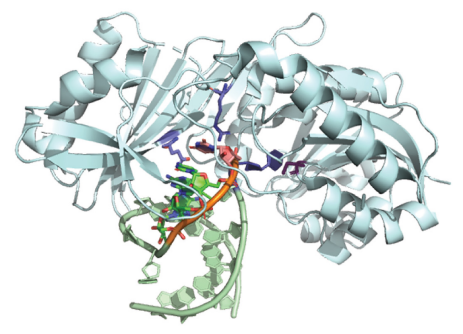

Catalysis of Modification

Product

Release

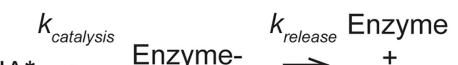

NA $\stackrel{+}{\gtrless}$ modified tRNA
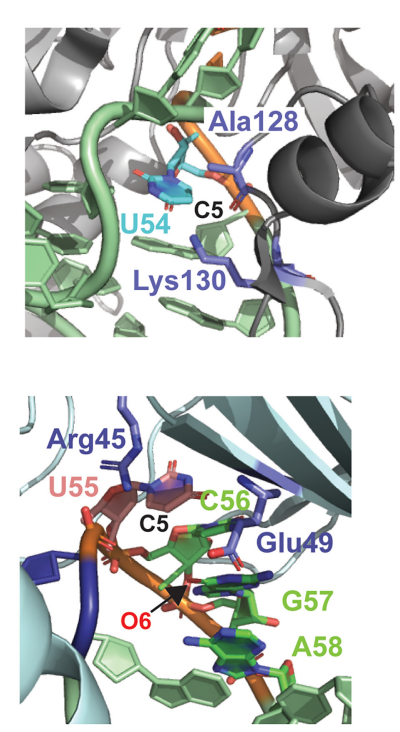

FIGURE 5. Kinetic mechanism and tRNA interactions of TruB and TrmA. (A) Both TruB and TrmA have a two-step tRNA binding mechanism where the tRNA is first docked onto the enzyme $\left(k_{1}, k_{-1}\right)$ followed by a conformational change that disrupts $T$ and $D$ arm interactions $\left(k_{2}\right.$, $k_{-2}$ ) such that the enzyme gains access to its target uridine. Both binding steps are reversible and contribute to the dissociation constant. Subsequently, the tRNA is modified in one or more catalytic steps ( $\left.k_{\text {catalysis }}\right)$, and finally the modified tRNA is released as the reaction product $\left(k_{\text {release }}\right)$. All steps can contribute to the overall velocity $\left(v_{0}\right)$ of the enzyme. $(B)$ Interaction of TruB with the T arm, in particular U54. (Left) Overview of TruB bound to the T arm (PDB ID $1 \mathrm{~K} 8 \mathrm{~W}$ [Hoang and Ferre-D'Amare 2001]). U54 is shown in cyan, U55 in orange, and the catalytic aspartate 48 in red. The thumb loop is depicted in dark gray. (Right) Close-up view on the interaction of Lys130 and Ala128 (purple) in the thumb loop with U54. The backbone oxygen of Ala128 is $3.8 \AA$ apart from C5 in U54 whereas the $\zeta N$ of Lys 130 is located $3.6 \AA$ away from C5 of U54. The site of methylation by TrmA, C5 in U54, is indicated suggesting that the methyl group would cause a steric clash with Lys130 and Ala128. (C) Interaction of TrmA with the T arm, in particular U55. (Left) Overview of TrmA bound to the T arm (PDB ID: 3BT7 [Alian et al. 2008]). U54 is shown in blue, the catalytic cysteine in purple, and U55 in orange. (Right) Close-up, back view of U55 stacking with C56, G57, and A58 (green). The position of C5 of U55 which would be occupied by N1 in pseudouridine is indicated. Residues Arg45 and Glu49 (purple) are in proximity of U55, but not in direct contact with $\mathrm{C} 5$, that is, N1 in $\Psi 55$ (3.1 A between the $\eta \mathrm{N}$ of Arg 45 and C5 of U55, and 5.9 A between the $\varepsilon \mathrm{O}$ of Glu49 and C5 of U55). A pseudouridine would further strengthen the depicted base stacking interactions of U55-C56-G57-A58 in the T loop. Moreover, a water molecule could potentially form a hydrogen bonding bridge between N1 of pseudouridine and O6 of G57 (4.3 ^ apart, labeled). All structural representations were prepared with the PyMOL software package.

to access their target base (Hoang and Ferre-D'Amare 2001; Ishitani et al. 2003). A rigid tRNA elbow already containing one or more modifications may provide TruB and ArcTGT with a greater challenge in the accession of their target base. Likewise, Bacillus subtilis TrmK methylates A22 and also prefers to bind to completely unmodified tRNA compared to tRNA containing prior modifications (Degut et al. 2019).

Similar to pseudouridylation by TruB, tRNA methylation at U54 by TrmA is affected by tRNA modifications. We found that TrmA is sensitive to the presence of $\mathrm{m}^{7} \mathrm{G} 46$ and 455 , but not $s^{4} \cup 8$. The presence of $\mathrm{m}^{7} \mathrm{G} 46$ decreases methylation activity and affinity for tRNA. Again, this effect is most likely a result of the stabilization of the $D$ arm by $m^{7} G 46$, which hinders the disruption of $T$ and $D$ arm interactions by TrmA (decreased $\left.k_{2}\right)$, causing a higher dissociation constant. We also observed that the presence of $\Psi 55$ decreases the initial velocity $\left(v_{0}\right)$ of methylation by $\operatorname{TrmA}$, but without affecting the catalytic step ( $\left.k_{\text {methyl }}\right)$ itself (Tables 1,2$)$. In contrast to the negative effect on multiple-turnover methylation, we surprisingly note that $\Psi 55$ has a positive effect on the affinity of TrmA for tRNA. As we will further explain below, these observations for $\Psi 55$ can only be explained if a forward reaction step other than catalysis is slowed down $\left(k_{1}, k_{2}\right.$, or $\left.k_{\text {release }}\right)$, reducing the multiple-turnover activity, and if a reverse reaction step (e.g., $k_{-2}$ ) is reduced even more, leading to tighter tRNA binding (Fig. 5A).

In the structure of TrmA bound to an unmodified $T$ arm, U55 forms base stacking interactions with nucleotides $56-58$, and the base of U55 is contacted by the side chain of Arginine 45 and the backbone of Glutamate 49 (Fig. 5C, PDB ID 3BT7; Alian et al. 2008). When U55 is converted to pseudouridine, N1 of pseudouridine will occupy the position of C5. None of TrmA's contacts with U55 involve this atom in the uracil ring such that it seems unlikely that TrmA residues directly sense the presence of $\Psi 55$. However, TrmA can only gain access to U54 by imposing a structural rearrangement in the T loop including formation of the base stack between U55, C56, G57, and A58 (Alian et al. 2008). As pseudouridine forms stronger base stacking interactions than uridine (Davis 1995), the presence of $\Psi 55$ will stabilize the $T$ arm conformation as bound to TrmA. In addition, it is conceivable that a water molecule could possibly form a hydrogen bonding bridge between $\mathrm{N} 1$ of $\Psi 55$ and $\mathrm{O} 6$ of G57, further rigidifying the base 
stacking interactions. The stabilization of the T arm conformation as bound to TrmA could reduce the dissociation of tRNA from TrmA ( $k_{-1}$ or $k_{-2}$, Fig. 5C) explaining the lower dissociation constant of TrmA for tRNA containing $\Psi 55$.

The initial velocity of tRNA methylation of TrmA, but not the catalytic rate, is reduced by $\Psi 55$, despite tighter binding of TrmA to tRNA containing $\Psi 55$. Thus surprisingly, despite tighter binding, the overall multiple-turnover reaction comprising all reaction steps is slower whereas the catalytic step is not directly affected. As mentioned, these observations can only be explained by slower tRNA binding $\left(k_{1}\right.$ or $\left.k_{2}\right)$ or slower product release, limiting the turnover of TrmA. Slower product release could be a result of more stable binding of tRNA containing $\Psi 55$ which should equally affect $k_{-2}$ and $k_{\text {release }}$ (Fig. 5A). The presence of $\Psi 55$ itself will also stabilize tertiary interactions within the tRNA substrate, rendering it possibly more difficult for TrmA to gain access to U54 when disrupting the interaction between the $D$ arm and the $T$ arm (reduced $k_{2}$ ), which may further contribute to the reduced multiple turnover rate of TrmA when $\Psi 55$ is present.

Notably, TrmB is not affected in its activity or tRNA binding by the presence of $\mathrm{m}^{5} \mathrm{U} 54$ or $\Psi 55$. Since no structure of TrmB bound to tRNA has been determined so far, we can only speculate whether and how TrmB interacts with other regions of the tRNA besides the variable loop. It may be that TrmB does not contact the T arm and that it does not affect the tertiary interaction between the $D$ and $T$ arm. Alternatively, TrmB may interact with the T arm, but this interaction may not be affected by $\mathrm{T}$ loop modifications.

\section{Preferred order of tRNA modification}

Based on our data, we hypothesize that there is a preferred order, although not a strict hierarchy, of tRNA modification in E. coli. Specifically, we propose that TruB and TrmA prefer to act earlier than TrmB and Thil during tRNA maturation. Since TruB and TrmA are faster acting on tRNA lacking other modifications (Table 1-3), TruB and TrmA are likely to act during the relatively early stages of tRNA maturation within the cell prior to TrmB introducing $m^{7} \mathrm{G} 46$ in the variable arm. This hypothesis is supported by our observations that $m^{7} \mathrm{G} 46$ presence negatively affects tRNA modification by TruB and TrmA, but TrmB is unaffected by $\mathrm{m}^{5} \mathrm{U} 54$ and $\Psi 55$. Accordingly, TrmB is hypothesized to preferably act after TrmA and TruB, but this does not mean that $E$. coli TrmB is acting late during tRNA modification as also observed in yeast (Barraud et al. 2019). Notably, a recent study uncovered that the presence of $m^{7} \mathrm{G} 46$ is highly advantageous for the formation of the adjacent aminocarboxypropyluridine (acp $\left.{ }^{3} U 47\right)$ modification in E. coli tRNA by the newly discovered YfiP/ TapT enzyme (Meyer et al. 2020). Conversely, TrmB does not depend on the prior formation of $\mathrm{acp}^{3} U 47$. Therefore, it is plausible that TruB and TrmA prefer to modify tRNA very early followed by TrmB, which methylates tRNA shortly after and before the likely late-acting TapT enzyme (Takakura et al. 2019; Meyer et al. 2020). The presence of the $s^{4} U 8$ modification did not affect the apparent rate of modification for either TrmA or TruB (Table 2; Figs. 2B, 3B); however, $\mathrm{s}^{4} \mathrm{U} 8$ presence did lower the affinity of TruB for tRNA ${ }^{\text {Phe }}$ (Table 3; Fig. 2C). From these data, we cannot decisively predict temporally when Thil is likely to act during tRNA maturation; however, it does seem probable that Thil may act after TruB in order to provide TruB with an ideal substrate.

In accordance with our suggestion that TruB and TrmA may act prior to TrmB during tRNA modification in $E$. coli, a similar preferred modification order was reported in a recent study of in vitro transcribed tRNA ${ }^{\text {Phe }}$ modification in Saccharomyces cerevisiae cell extracts monitored by time-resolved NMR. Here, $\Psi 55$ was the first modification to be introduced within tRNA, with both $\mathrm{m}^{5} \mathrm{U} 54$ and $m^{7} \mathrm{G} 46$ appearing second within the tRNA where the introduction of $\mathrm{m}^{7} \mathrm{G} 46$ finished after the complete introduction of $m^{5} U 54$ (Barraud et al. 2019). Thus, in both E. coli and $S$. cerevisiae, TruB prefers to act prior to TrmB. But in yeast, it could be possible that TrmB and TrmA homologs act in parallel during tRNA maturation, which may be a result of species-specific differences between monomeric $E$. coli TrmB (Zhou et al. 2009) and the heterodimeric Trm8Trm82 complex from yeast (Alexandrov et al. 2002).

Regarding tRNA modification by TruB and TrmA in E. coli, the most likely temporal order is not obvious because $m^{5} U 54$ hinders TruB binding and $\Psi 55$ slows modification by TrmA (Table 1-3). On the other hand, $\Psi 55$ presence increases the affinity of TrmA for tRNA ${ }^{\text {Phe }}$ approximately fivefold (Table 3). The seemingly opposite effects of $\Psi 55$ on TrmA are not without precedence as the apparent rate of U34 modification by CmoM is decreased when 1-methylguanosine 37 formed by TrmD is present within E. coli tRNA ${ }^{\text {Pro }}$ UGG, despite 1-methylguanosine 37 lowering the affinity of CmoM for tRNA ${ }^{\text {Pro }}$ UG (Masuda et al. 2018). Interestingly, bulk tRNAs from yeast missing TruB's homolog, Pus4, have been found to lack $m^{5} U 54$ content, suggesting, at least in yeast, introduction of $m^{5} U 54$ actually relies on previous modification by TruB to a certain extent (Barraud et al. 2019). Accordingly, the yeast tRNA methyltransferase Trm2 may be differently affected by the presence of $\Psi 55$ than its $E$. coli homolog TrmA.

Several reasons support our suggestion that both TruB and TrmA modify tRNA relatively early within the overall hierarchy of tRNA modifications. First, with TrmA and TruB as the only enzymes to modify all species of $E$. coli tRNA, it seems unlikely for these enzymes to rely on the previous introduction of another tRNA modification as a positive determinant as no other modification can be present within each of their substrate tRNAs. In contrast, it is possible for other modification enzymes to rely on either $\mathrm{m}^{5} \mathrm{U} 54$ or $\Psi 55$ modifications as a determinant, considering that 
$\mathrm{m}^{5} \mathrm{U} 54$ and $\Psi 55$ conversely are present within the tRNA substrates of every E. coli tRNA modification enzyme. Second, evidence for early tRNA modification by TrmA and TruB during tRNA maturation is provided by the observation that both $\mathrm{m}^{5} \mathrm{U} 54$ and $\Psi 55$ appear prior to intron splicing and $5^{\prime}$ and $3^{\prime}$ end trimming when yeast tRNA ${ }^{\text {Tyr }}$ was injected into Xenopus oocytes (Nishikura and De Robertis 1981). Similarly, yeast tRNA $^{\text {Phe }}$ contains $\mathrm{m}^{5} \mathrm{U} 54$ and $\Psi 55$ prior to intron splicing (Etcheverry et al. 1979; Jiang et al. 1997). Third, considering that both TruB and TrmA are known tRNA chaperones (Keffer-Wilkes et al. 2016; LC Keffer-Wilkes, EF Soon, and U Kothe, in prep.), a scenario in which TruB and TrmA have evolved to interact with tRNA during the early stages of its maturation in order to quickly promote correct tRNA fold may be beneficial. In particular, the correct three-dimensional structure of tRNA promoted by the action of TruB and TrmA will allow the tRNA to be modified by other RRNA modification enzymes that recognize the entire tRNA structure (Grosjean et al. 1996).

\section{Conclusion}

In summary, our proof-of-principle study describes that TruB and TrmA prefer to act on unmodified tRNA compared to tRNA already containing a single modification whereas TrmB does not appear to have a preference for the modification status of tRNA. Our results corroborate recent findings in yeast (Barraud et al. 2019) and additionally provide mechanistic insight for why $\Psi 55$ and $\mathrm{m}^{5} \mathrm{U} 54$ are likely to appear early during tRNA maturation. A recent review (Han and Phizicky 2018) hypothesized that tRNA modification circuits, that is, a strict order of modification, are most common within the anticodon loop because modifications can serve as additional sequence or structure determinants to ensure tRNA anticodon loop modification enzymes only modify their desired substrates, which is particularly critical considering the diversity of anticodon loop modification and its importance for translational fidelity. Taking our results together with other studies of tRNA elbow modification enzymes (Rider et al. 2009; Nomura et al. 2016; Barraud et al. 2019; Degut et al. 2019; Hori 2019; Meyer et al. 2020), it becomes clear that modifications in the tRNA elbow region do not occur in strict order where one modification is dependent on the other. However, there is still a preferred pathway of tRNA elbow modification and the modification enzymes do not act randomly on tRNA.

\section{MATERIALS AND METHODS}

\section{Buffers and reagents}

Experiments were performed in $\mathrm{TAKEM}_{4}$ buffer $(50 \mathrm{mM}$ Tris- $\mathrm{HCl}$, $\mathrm{pH}$ 7.5, $70 \mathrm{mM} \mathrm{NH}_{4} \mathrm{Cl}, 30 \mathrm{mM} \mathrm{KCl}, 1 \mathrm{mM}$ EDTA, $4 \mathrm{mM} \mathrm{MgCl} 2$ ). $\left[\mathrm{C} 5-{ }^{3} \mathrm{H}\right] \mathrm{UTP}$ for in vitro transcription of $\left[{ }^{3} \mathrm{H}\right] \mathrm{tRNA}{ }^{\mathrm{Phe}}$ was purchased from Moraveck Biochemicals and radioactive adenosyl-L-methionine $S$-[methyl- $\left.{ }^{3} \mathrm{H}\right]\left(\left[{ }^{3} \mathrm{H}\right] \mathrm{SAM}\right)$ was purchased from PerkinElmer. Nonradioactive SAM was obtained from New England Biolabs (NEB). All other chemicals were purchased from Fisher Scientific.

\section{Protein expression and purification}

To generate a plasmid encoding $E$. coli $\operatorname{trm} B$, the forward primer, 5'-GCCAGAGCTAGCAAAAACGACGTCATTTCAC CG-3' and reverse primer, 5'-GCCACCGGATCCTTATTTCACCC TCTCGAACATTAAGTCCC-3' were used to amplify the trmB open reading frame and clone into the $\mathrm{pET} 28 \mathrm{a}(+)$ vector using the Nhel and BamHI restriction sites, creating pET28a-TrmB. The gene sequence was confirmed by DNA sequencing (Genewiz) and the plasmid was transformed into BL21 (DE3) cells. Cells were grown in LB supplemented with $50 \mu \mathrm{g} / \mathrm{mL}$ kanamycin at $37^{\circ} \mathrm{C}$ and protein expression was induced at an $\mathrm{OD}_{600}$ of approximately 0.6 with $1 \mathrm{mM}$ isopropyl $\beta$-D-1-thiogalactopyranoside (IPTG). After $3 \mathrm{~h}$, cells were harvested by centrifugation at $5000 \mathrm{~g}$ for $15 \mathrm{~min}$, flash frozen, and stored at $-80^{\circ} \mathrm{C}$.

Wild-type TruB and TruB D48N were expressed from pET28aTruB in BL21 (DE3) cells as previously described (Wright et al. 2011). For the expression of Thil and IscS in BL21 (DE3) cells, plasmids pBH113 and pBH402 were obtained from Eugene Mueller (Mueller et al. 1998, 2001). TrmA wild-type and TrmA C324A proteins were overexpressed from the pCA24N(GFP minus)-TrmA (JW3937) plasmid in AG1 (ME5305) cells (Kitagawa et al. 2005; LC Keffer-Wilkes, EF Soon, and U Kothe, in prep.). Similarly, the tRNA pseudouridine synthases TruA and RluA were expressed using the respective pCA24N(GFP minus) plasmids (Wright et al. 2011).

All proteins were purified via their amino-terminal hexahistidine tag using nickel-sepharose and Superdex 75 chromatography as described (Wright et al. 2011). Protein concentrations were determined by absorbance at $280 \mathrm{~nm}$ using molar extinction coefficients of $35,870 \mathrm{M}^{-1} \mathrm{~cm}^{-1}$ for TrmA, 20,860 M-1 $\mathrm{cm}^{-1}$ for TruB, and $27,960 \mathrm{M}^{-1} \mathrm{~cm}^{-1}$ for TrmB (calculated using ProtParam [Gill and von Hippel 1989]), 63,100 $\mathrm{M}^{-1} \mathrm{~cm}^{-1}$ for Thil and 25,400 $\mathrm{M}^{-1} \mathrm{~cm}^{-1}$ for IscS (as determined in Mueller et al. 2001). Concentrations were confirmed using comparative SDS-PAGE.

\section{tRNA preparation}

The E. coli $t R N A^{\text {Phe }}$ gene was amplified from the pCFO plasmid (Sampson et al. 1989) for in vitro transcription. To produce internally tritium-labeled tRNA, [C5- $\left.{ }^{3} \mathrm{H}\right]$ UTP was included in the reaction as previously described (Wright et al. 2011). Radioactive tRNA ${ }^{\text {Phe }}$ transcripts were purified by Nucleobond Xtra Midi anion-exchange gravity columns (Macherey-Nagel) as described (Wright et al. 2011). Nonradioactive transcripts were purified by phenol-chloroform extraction to remove proteins followed by Superdex 75 (XK 26/100 column, GE Healthcare) size exclusion chromatography to remove unincorporated nucleotides. Subsequently, tRNA ${ }^{\text {Phe }}$ was concentrated by isopropanol precipitation and resuspended in water. tRNA ${ }^{\text {Phe }}$ concentration was determined by $A_{260}$ measurements using a molar extinction coefficient of $500,000 \mathrm{M}^{-1} \mathrm{~cm}^{-1}$ (Peterson and Uhlenbeck 1992). Scintillation counting was used to determine the specific activity of radioactive tRNA. 


\section{Partial modification of tRNA ${ }^{\text {Phe }}$}

In vitro transcribed tRNA ${ }^{\text {Phe }}$ was refolded in $\mathrm{TAKEM}_{4}$ buffer by heating to $65^{\circ} \mathrm{C}$ for $5 \mathrm{~min}$ and cooled to room temperature for $10 \mathrm{~min}$. To prepare single-modified tRNA $^{\text {Phe }} \Psi 55$, tRNA ${ }^{\text {Phe }}$ $m^{5} U 54$, and tRNA ${ }^{\text {Phe }} m^{7} \mathrm{G} 46,1.6 \mu \mathrm{M}$ of tritium-labeled or nonradioactive refolded tRNA ${ }^{\text {Phe }}$ was incubated with $5 \mu \mathrm{M}$ of purified TruB, TrmA, or TrmB enzyme for $2 \mathrm{~h}$ at $37^{\circ} \mathrm{C}$ in a $5 \mathrm{~mL}$ reaction. Methylation reactions included $50 \mu \mathrm{M}$ SAM. To prepare $\left[{ }^{3} \mathrm{H}\right]$ tRNA $^{\text {Phe }} s^{4} U 8,4 \mu \mathrm{M}$ of folded $\left[{ }^{3} \mathrm{H}\right] \mathrm{tRNA} \mathrm{A}^{\text {Phe }}, 2 \mu \mathrm{M}$ of purified Thil, and $1 \mu \mathrm{M}$ purified IscS was incubated with $40 \mu \mathrm{M}$ pyridoxal-5'phosphate, $4 \mathrm{mM} \mathrm{ATP}, 0.5 \mathrm{mM}$ L-cysteine, and $1 \mathrm{mM}$ DTT in a $10 \mathrm{~mL}$ reaction volume in $\mathrm{TAKEM}_{4}$ buffer for $2 \mathrm{~h}$ at $37^{\circ} \mathrm{C}$. To prepare a $\left[{ }^{3} \mathrm{H}\right] \mathrm{tRNA}{ }^{\text {Phe }}$ with five modifications, $5 \mu \mathrm{M}\left[{ }^{3} \mathrm{H}\right] \mathrm{tRNA}{ }^{\text {Phe }}$ was incubated with $7.5 \mu \mathrm{M}$ of each RluA, TruA, TruB, TrmA, and TrmB in the presence of $50 \mu \mathrm{M}$ SAM in a $100 \mu \mathrm{L}$ reaction. In all cases, enzymes were subsequently removed by phenol-chloroform extraction followed by ethanol precipitation of the tRNA. After resuspending modified tRNA ${ }^{\text {Phe }}$ in water, $t R N A^{\text {Phe }}$ concentration was determined by $A_{260}$ measurements and scintillation counting.

To quantify the level of modification for prepared $\left[{ }^{3} \mathrm{H}\right] \mathrm{tRNA} \mathrm{A}^{\text {Phe }}$ $m^{5} U 54$ and $\left[{ }^{3} \mathrm{H}\right]$ tRNA ${ }^{\text {Phe }} \Psi 55,600 \mathrm{nM}$ of the now single-modified tRNA was incubated with $5 \mu \mathrm{M}$ TrmA or TruB, respectively. The end level of modification by the enzyme after $1 \mathrm{~h}$ at $37^{\circ} \mathrm{C}$ was determined in triplicate by tritium release assays in order to determine the percentage of the tRNA that had remained unmodified. Thereby, it was determined that $\left[{ }^{3} \mathrm{H}\right] \mathrm{tRNA} \mathrm{A}^{\text {Phe }}$ $m^{5} \cup 54$ was $78 \pm 5 \%$ modified and $\left[{ }^{3} \mathrm{H}\right] \mathrm{tRNA}{ }^{\text {Phe }} \Psi 55$ was $81 \pm 4 \%$ modified. The $\Psi 55$ content within the $\left[{ }^{3} \mathrm{H}\right] \mathrm{tRNA}{ }^{\text {Phe }}$ with five modifications was similarly quantified, and $\Psi 55$ was found to be present in $83 \pm 3 \%$ of this preparation. To assess the level of modification within $\left[{ }^{3} \mathrm{H}\right] \mathrm{tRNA}{ }^{\text {Phe }} \mathrm{m}^{7} \mathrm{G} 46$ and nonradioactive tRNA $^{\text {Phe }} \mathrm{m}^{5} \mathrm{U} 54$ and tRNA ${ }^{\text {Phe }} \Psi 55$ preparations, small scale reactions with $\left[{ }^{3} \mathrm{H}\right] \mathrm{SAM}$ or $\left[{ }^{3} \mathrm{H}\right] \mathrm{tRNA}{ }^{\text {Phe }}$ were performed in parallel in triplicate to estimate the level of modification within each respective large-scale preparation. The respective tRNA ${ }^{\text {Phe }}$ preparations contained $83 \pm 5 \%$ of $m^{7} G 46,88 \pm 2 \%$ of $m^{5} U 54$, and $89 \pm 3 \%$ of $\Psi 55$. Finally, to quantify the level of $s^{4} \cup 8$ within tRNA, modified tRNA was analyzed in triplicate on an [(N-acryloylamino)phenyl] mercuric chloride (APM) gel (Igloi 1988). In brief, 50 pmol of RNA was analyzed on a denaturing gel containing $10 \%$ acrylamide (19:1 acrylamide:bisacrylamide), 7 M urea, and $20 \mu$ M APM in Tris/ Borate/EDTA (TBE) buffer. Following SYBR Green II staining, the ratio of thiolated tRNA retarded by APM to nonthiolated, faster migrating tRNA was determined using ImageJ software and $\left[{ }^{3} \mathrm{H}\right]$ tRNA ${ }^{\text {Phe }} s^{4} U 8$ was determined to be $83 \pm 2 \%$ modified.

\section{Tritium release assay to measure $\Psi 55$ and $m^{5} \mathrm{U} 54$ formation}

Tritium release assays were performed as previously described to detect pseudouridylation by TruB and C5-methylation by TrmA (Wright et al. 2011; LC Keffer-Wilkes, EF Soon, and U Kothe, in prep.). First, tritium-labeled tRNA ${ }^{\text {Phe }}$ was refolded as before. All reactions with TrmA included $50 \mu \mathrm{M}$ SAM. For multiple-turnover reactions, $600 \mathrm{nM}\left[{ }^{3} \mathrm{H}\right] \mathrm{tRNA}{ }^{\text {Phe }}$ was incubated with $10 \mathrm{nM}$ enzyme. The initial velocity $\left(v_{0}\right)$ of the reaction was determined by linear fitting of the first $1.5 \mathrm{~min}$ of the reaction. For single-turnover reactions, enzyme and $\left[{ }^{3} \mathrm{H}\right] \mathrm{tRNA} \mathrm{A}^{\text {Phe }}$ were mixed in a Kintek quench-flow with final concentrations of $5 \mu \mathrm{M}$ of enzyme and 1 $\mu \mathrm{M}$ of tRNA. Reactions were stopped by addition of $0.1 \mathrm{M}$ hydrochloric acid after $0.1,0.5,1,2,3,5,7.5,10,30,60$, and $180 \mathrm{sec}$, and the level of tritium released was determined as previously described (Wright et al. 2011). To determine the apparent reaction rate $\left(k_{\text {app }}\right)$, time courses were fit with a one-exponential equation:

$$
Y=Y_{0}+\left(Y_{\infty}-Y_{0}\right) \times \exp \left(-k_{\text {app }} \times t\right),
$$

where $Y$ is the percentage of pseudouridine formation at a given time point, $Y_{0}$ is the initial level of apparent pseudouridylation (due to tritium release from the tRNA in absence of enzyme), $Y_{\infty}$ is the endlevel of pseudouridylation, and $t$ is the time.

For TruB and TrmA, the apparent reaction rate is concentrationindependent and therefore directly reflects the rate constant of pseudouridylation $\left(k_{\Psi}\right)$ and the rate constant of methylation $\left(k_{\text {methyl }}\right)$, respectively (Wright et al. 2011; LC Keffer-Wilkes, EF Soon, and U Kothe, in prep.).

\section{Methylation assay to measure $m^{7} \mathrm{G} 46$ formation}

To determine methylation by $\operatorname{TrmB}, \operatorname{TrmB}$ and $\left[{ }^{3} \mathrm{H}\right] \mathrm{SAM}$ were rapidly mixed in a quench-flow apparatus with nonradioactive tRNA $^{\text {Phe }}$ to final concentrations $5 \mu \mathrm{M}, 50 \mu \mathrm{M}$, and $1 \mu \mathrm{M}$, respectively, and reactions were stopped by addition of $0.1 \mathrm{M} \mathrm{HCl}$ at the same timepoints as described above. A constant volume of each quenched sample was precipitated on Whatman paper disks presoaked with $5 \%(\mathrm{w} / \mathrm{v})$ trichloracetic acid. To remove unincorporated $\left[{ }^{3} \mathrm{H}\right] \mathrm{SAM}$, disks were washed three times with $5 \%(\mathrm{w} / \mathrm{v})$ trichloracetic acid for $5 \mathrm{~min}$ followed by a final wash in ethanol. After drying, paper disks were added to $4 \mathrm{~mL}$ EcoLite(+) scintillation cocktail (MP Biomedical), and the amount of $\left[{ }^{3} \mathrm{H}\right]$ methyl incorporated was determined by scintillation counting. The apparent rate of methylation was determined by fitting to a single exponential function, as stated above. Since percent tRNA methylated cannot be determined directed with this assay, the maximum amplitude determined by fitting was set to be $100 \%$.

\section{Nitrocellulose filtration to determine the affinity for tRNA}

Refolded, uniformly tritium-labeled tRNA ${ }^{\text {Phe }}(20-40 \mathrm{nM})$ was incubated with increasing concentrations of enzyme $(0,0.5,1.0,2.0$, 3.0, 5.0, 7.5, 10.0, 15.0, 30.0 $\mu \mathrm{M}$ for TruB D48N and wild-type TrmB, and 0, 0.15, 0.2, 0.3, 0.75, 1.0, 3.0, 5.0, 15.0, 30.0 $\mu \mathrm{M}$ for TrmA C324A) in TAKEM $_{4}$ buffer for $10 \mathrm{~min}$ at room temperature prior to filtration through a nitrocellulose membrane. The proportion of tRNA bound to enzyme was determined by scintillation counting as described in (Wright et al. 2011). The dissociation constant $\left(K_{D}\right)$ was determined by plotting percent RNA bound (Bound) as a function of enzyme concentration ([enzyme]) and fitting to a hyperbolic equation:

$$
\text { Bound }=\text { Bound }_{\max } \times[\text { enzyme }] /\left(K_{D}+[\text { enzyme }]\right) .
$$

\section{ACKNOWLEDGMENTS}

We thank Saskia Funk for preparation of Thil and IscS proteins, and the National BioResource Project (National Institute of Genetics, Japan) for the TrmA expression plasmid. In addition, 
we are grateful for the gift of Thil and IscS expression plasmids by Dr. Eugene Mueller. This work was supported by the Natural Sciences and Engineering Research Council of Canada (Discovery Grant RGPIN-2014-05954).

Received March 25, 2020; accepted May 4, 2020.

\section{REFERENCES}

Alexandrov A, Martzen MR, Phizicky EM. 2002. Two proteins that form a complex are required for 7-methylguanosine modification of yeast tRNA. RNA 8: 1253-1266. doi:10.1017/S13558382020 24019

Alexandrov A, Chernyakov I, Gu W, Hiley SL, Hughes TR, Grayhack EJ, Phizicky EM. 2006. Rapid tRNA decay can result from lack of nonessential modifications. Mol Cell 21: 87-96. doi:10.1016/j.molcel .2005 .10 .036

Alian A, Lee TT, Griner SL, Stroud RM, Finer-Moore J. 2008. Structure of a TrmA-RNA complex: a consensus RNA fold contributes to substrate selectivity and catalysis in $\mathrm{m}^{5} \mathrm{U}$ methyltransferases. Proc Natl Acad Sci 105: 6876-6881. doi:10.1073/pnas.0802247105

Barraud P, Tisne C. 2019. To be or not to be modified: miscellaneous aspects influencing nucleotide modifications in tRNAs. IUBMB Life 71: 1126-1140. doi:10.1002/iub.2041

Barraud P, Gato A, Heiss M, Catala M, Kellner S, Tisne C. 2019. Timeresolved NMR monitoring of tRNA maturation. Nat Commun 10: 3373. doi:10.1038/s41467-019-11356-w

Boccaletto P, Machnicka MA, Purta E, Piatkowski P, Baginski B, Wirecki TK, de Crecy-Lagard V, Ross R, Limbach PA, Kotter A, et al. 2018. MODOMICS: a database of RNA modification pathways. 2017 update. Nucleic Acids Res 46: D303-D307. doi:10 $.1093 /$ nar/gkx1030

Byrne RT, Konevega AL, Rodnina MV, Antson AA. 2010. The crystal structure of unmodified tRNA ${ }^{\text {phe }}$ from Escherichia coli. Nucleic Acids Res 38: 4154-4162. doi:10.1093/nar/gkq133.

Davis DR. 1995. Stabilization of RNA stacking by pseudouridine. Nucleic Acids Res 23: 5020-5026. doi:10.1093/nar/23.24.5020

de Crecy-Lagard V, Boccaletto P, Mangleburg CG, Sharma P, Lowe TM, Leidel SA, Bujnicki JM. 2019. Matching tRNA modifications in humans to their known and predicted enzymes. Nucleic Acids Res 47: 2143-2159. doi:10.1093/nar/gkz011

Degut C, Roovers M, Barraud P, Brachet F, Feller A, Larue V, Al Refaii A, Caillet J, Droogmans L, Tisne C. 2019. Structural characterization of $B$. subtilis $\mathrm{m}^{1} \mathrm{~A}_{22}$ tRNA methyltransferase TrmK: insights into tRNA recognition. Nucleic Acids Res 47: 4736-4750. doi:10.1093/nar/gkz230

El Yacoubi B, Bailly M, de Crecy-Lagard V. 2012. Biosynthesis and function of posttranscriptional modifications of transfer RNAs. Annu Rev Genet 46: 69-95. doi:10.1146/annurev-genet-110711155641

Etcheverry T, Colby D, Guthrie C. 1979. A precursor to a minor species of yeast tRNA ${ }^{\text {Ser }}$ contains an intervening sequence. Cell 18: 11-26. doi:10.1016/0092-8674(79)90349-0

Friedt J, Leavens FM, Mercier E, Wieden HJ, Kothe U. 2014. An arginine-aspartate network in the active site of bacterial TruB is critical for catalyzing pseudouridine formation. Nucleic Acids Res 42: 3857-3870. doi:10.1093/nar/gkt1331

Gill SC, von Hippel PH. 1989. Calculation of protein extinction coefficients from amino acid sequence data. Anal Biochem 182: 319326. doi:10.1016/0003-2697(89)90602-7

Grosjean H, Edqvist J, Straby KB, Giege R. 1996. Enzymatic formation of modified nucleosides in tRNA: dependence on tRNA architecture. J Mol Biol 255: 67-85. doi:10.1006/jmbi.1996.0007
Han L, Phizicky EM. 2018. A rationale for tRNA modification circuits in the anticodon loop. RNA 24: 1277-1284. doi:10.1261/rna.067736 .118

Helm M. 2006. Post-transcriptional nucleotide modification and alternative folding of RNA. Nucleic Acids Res 34: 721-733. doi:10 $.1093 /$ nar/gkj471

Hoang C, Ferre-D'Amare AR. 2001. Cocrystal structure of a tRNA 455 pseudouridine synthase: nucleotide flipping by an RNA-modifying enzyme. Cell 107: 929-939. doi:10.1016/S0092-8674(01) 00618-3

Hori H. 2019. Regulatory factors for tRNA modifications in extremethermophilic bacterium Thermus thermophilus. Front Genet 10: 204. doi:10.3389/fgene.2019.00204

Igloi GL. 1988. Interaction of tRNAs and of phosphorothioate-substituted nucleic acids with an organomercurial. Probing the chemical environment of thiolated residues by affinity electrophoresis. Biochemistry 27: 3842-3849. doi:10.1021/bi00410a048

Ishitani R, Nureki O, Nameki N, Okada N, Nishimura S, Yokoyama S. 2003. Alternative tertiary structure of tRNA for recognition by a posttranscriptional modification enzyme. Cell 113: 383-394. doi:10.1016/S0092-8674(03)00280-0

Jiang HQ, Motorin Y, Jin YX, Grosjean H. 1997. Pleiotropic effects of intron removal on base modification pattern of yeast tRNA ${ }^{\text {Phe }}$ : an in vitro study. Nucleic Acids Res 25: 2694-2701. doi:10.1093/ nar/25.14.2694

Kambampati R, Lauhon CT. 2000. Evidence for the transfer of sulfane sulfur from IscS to Thil during the in vitro biosynthesis of 4-thiouridine in Escherichia coli tRNA. J Biol Chem 275: 10727-10730. doi:10.1074/jbc.275.15.10727

Kealey JT, Gu X, Santi DV. 1994. Enzymatic mechanism of tRNA ( $\left.m^{5} \cup 54\right)$ methyltransferase. Biochimie 76: 1133-1142. doi:10 .1016/0300-9084(94)90042-6

Keffer-Wilkes LC, Veerareddygari GR, Kothe U. 2016. RNA modification enzyme TruB is a tRNA chaperone. Proc Natl Acad Sci 113: 14306-14311. doi:10.1073/pnas. 1607512113

Kimura S, Waldor MK. 2019. The RNA degradosome promotes tRNA quality control through clearance of hypomodified tRNA. Proc Natl Acad Sci 116: 1394-1403. doi:10.1073/pnas.1814130116

Kitagawa M, Ara T, Arifuzzaman M, loka-Nakamichi T, Inamoto E, Toyonaga H, Mori H. 2005. Complete set of ORF clones of Escherichia coli ASKA library (A Complete Set of E. coli K-12 ORF Archive): unique resources for biological research. DNA Res 12: 291-299. doi:10.1093/dnares/dsi012

Masuda I, Takase R, Matsubara R, Paulines MJ, Gamper H, Limbach PA, Hou YM. 2018. Selective terminal methylation of a tRNA wobble base. Nucleic Acids Res 46: e37. doi:10.1093/nar/ gky013

Meyer B, Immer C, Kaiser S, Sharma S, Yang J, Watzinger P, Weiss L, Kotter A, Helm M, Seitz HM, et al. 2020. Identification of the 3-amino-3-carboxypropyl (acp) transferase enzyme responsible for acp $^{3} U$ formation at position 47 in Escherichia coli tRNAs. Nucleic Acids Res 48: 1435-1450. doi:10.1093/nar/gkz1191

Mueller EG, Buck CJ, Palenchar PM, Barnhart LE, Paulson JL. 1998. Identification of a gene involved in the generation of 4-thiouridine in tRNA. Nucleic Acids Res 26: 2606-2610. doi:10.1093/nar/26.11 .2606

Mueller EG, Palenchar PM, Buck CJ. 2001. The role of the cysteine residues of Thil in the generation of 4-thiouridine in tRNA. J Biol Chem 276: 33588-33595. doi:10.1074/jbc.M104067200

Nishikura K, De Robertis EM. 1981. RNA processing in microinjected Xenopus oocytes. Sequential addition of base modifications in the spliced transfer RNA. J Mol Biol 145: 405-420. doi:10.1016/00222836(81)90212-6

Nomura Y, Ohno S, Nishikawa K, Yokogawa T. 2016. Correlation between the stability of tRNA tertiary structure and the catalytic 


\section{Schultz and Kothe}

efficiency of a tRNA-modifying enzyme, archaeal tRNAguanine transglycosylase. Genes Cells 21: 41-52. doi:10.1111/ gtc. 12317

Peterson ET, Uhlenbeck OC. 1992. Determination of recognition nucleotides for Escherichia coli phenylalanyl-tRNA synthetase. Biochemistry 31: 10380-10389. doi:10.1021/bi0015 $7 \mathrm{a} 028$

Purta E, van Vliet F, Tricot C, De Bie LG, Feder M, Skowronek K, Droogmans L, Bujnicki JM. 2005. Sequence-structure-function relationships of a tRNA ( $\left.\mathrm{m}^{7} \mathrm{G} 46\right)$ methyltransferase studied by homology modeling and site-directed mutagenesis. Proteins 59: 482-488. doi:10.1002/prot.20454

Ranjan N, Rodnina MV. 2016. tRNA wobble modifications and protein homeostasis. Translation (Austin) 4: e1143076. doi:10.1080/ 21690731.2016.1143076

Rider LW, Ottosen MB, Gattis SG, Palfey BA. 2009. Mechanism of dihydrouridine synthase 2 from yeast and the importance of modifications for efficient tRNA reduction. J Biol Chem 284: 1032410333. doi:10.1074/jbc.M806137200

Sampson JR, DiRenzo AB, Behlen LS, Uhlenbeck OC. 1989. Nucleotides in yeast tRNA ${ }^{\text {Phe }}$ required for the specific recognition by its cognate synthetase. Science 243: 1363-1366. doi:10.1126/ science. 2646717

Sokolowski M, Klassen R, Bruch A, Schaffrath R, Glatt S. 2018. Cooperativity between different tRNA modifications and their modification pathways. Biochim Biophys Acta Gene Regul Mech 1861: 409-418. doi:10.1016/j.bbagrm.2017.12.003
Takakura M, Ishiguro K, Akichika S, Miyauchi K, Suzuki T. 2019. Biogenesis and functions of aminocarboxypropyluridine in tRNA. Nat Commun 10: 5542. doi:10.1038/s41467-019-13525-3

Thongdee N, Jaroensuk J, Atichartpongkul S, Chittrakanwong J, Chooyoung K, Srimahaeak T, Chaiyen P, Vattanaviboon P, Mongkolsuk S, Fuangthong M. 2019. TrmB, a tRNA m7 46 methyltransferase, plays a role in hydrogen peroxide resistance and positively modulates the translation of katA and katB mRNAs in Pseudomonas aeruginosa. Nucleic Acids Res 47: 9271-9281. doi:10.1093/nar/gkz702

Tomikawa C. 2018. 7-methylguanosine modifications in transfer RNA (tRNA). Int J Mol Sci 19: E4080. doi:10.3390/ijms19124080

Urbonavicius J, Durand JM, Bjork GR. 2002. Three modifications in the $\mathrm{D}$ and $\mathrm{T}$ arms of tRNA influence translation in Escherichia coli and expression of virulence genes in Shigella flexneri. J Bacteriol 184: 5348-5357. doi:10.1128/JB.184.19.5348-5357.2002

Veerareddygari GR, Singh SK, Mueller EG. 2016. The pseudouridine synthases proceed through a glycal intermediate. J Am Chem Soc 138: 7852-7855. doi:10.1021/jacs.6b04491

Wright JR, Keffer-Wilkes LC, Dobing SR, Kothe U. 2011. Pre-steadystate kinetic analysis of the three Escherichia coli pseudouridine synthases TruB, TruA, and RluA reveals uniformly slow catalysis. RNA 17: 2074-2084. doi:10.1261/rna.2905811

Zhou H, Liu Q, Yang W, Gao Y, Teng M, Niu L. 2009. Monomeric tRNA $\left(m^{7} \mathrm{G} 46\right)$ methyltransferase from Escherichia coli presents a novel structure at the function-essential insertion. Proteins 76: 512515. doi:10.1002/prot.22413 

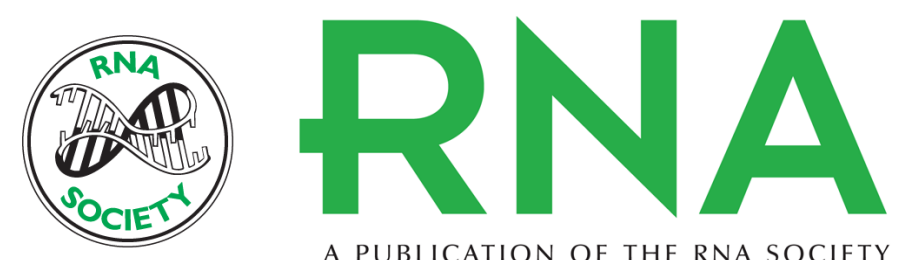

A PUBLICATION OF THE RNA SOCIETY

\title{
tRNA elbow modifications affect the tRNA pseudouridine synthase TruB and the methyltransferase TrmA
}

\author{
Sarah Kai-Leigh Schultz and Ute Kothe
}

RNA 2020 26: 1131-1142 originally published online May 8, 2020

Access the most recent version at doi:10.1261/rna.075473.120

\section{References This article cites 45 articles, 11 of which can be accessed free at: http://rnajournal.cshlp.org/content/26/9/1131.full.html\#ref-list-1 \\ Creative This article is distributed exclusively by the RNA Society for the first 12 months after the Commons full-issue publication date (see http://rnajournal.cshlp.org/site/misc/terms.xhtml). After 12 License months, it is available under a Creative Commons License (Attribution-NonCommercial 4.0 International), as described at http://creativecommons.org/licenses/by-nc/4.0/.}

Email Alerting Receive free email alerts when new articles cite this article - sign up in the box at the Service top right corner of the article or click here.

\section{III!" P Providing Precise Solutions tor your research.}

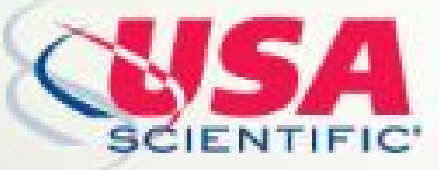

To subscribe to $R N A$ go to:

http://rnajournal.cshlp.org/subscriptions

(C) 2020 Schultz and Kothe; Published by Cold Spring Harbor Laboratory Press for the RNA Society 